\title{
BEYOND ENVIRONMENTAL SECURITY: COMPLEX SYSTEMS, MULTIPLE INEQUALITIES AND ENVIRONMENTAL RISKS
}

\author{
Erika Cudworth ${ }^{*}$ and Stephen Hobden \\ School of Humanities and Social Sciences, University of East London, UK
}

\begin{abstract}
The development of environmental security as an academic project is an important contribution in theorising the politics of global environmental change and shifting security contexts. However, there are significant problems with the ways in which environmental issues have been incorporated into security discussions. This paper considers different approaches to theorising environmental questions in international politics: environmental conflict, environmental security and ecological security. The first two of these tend to reproduce a dualistic understanding of human relations to 'the environment' in which humans are either threatened by or pose a threat to 'nature'. The latter approach does account for changes in the biosphere resultant from human endeavours, and understands social relations as ecologically embedded. However, it underplays the extent to which multiple and complex inequalities shape the environmental impact of different populations.
\end{abstract}

Drawing on concepts from complexity theory, alongside different elements of political ecologism, this paper argues that human relations to environments are characterised by social intersectionality and complex inequalities. It suggests that complexity approaches can help capture the patterns of these relations, and understand the co-constitution of human communities and the 'natural environment'.

\begin{abstract}
Keywords: Environmental security; social ecologism; intersectionality; multiple inequalities, complexity theory
\end{abstract}

\section{Introduction}

The term 'environmental security' has rapidly entered the lexicon of discussions about security, at academic, popular and policy levels. We welcome the increased significance that the term implies for the study of environmental issues, yet there are significant problems with the ways in which environmental issues have been incorporated into security discussions. This article argues for a complex ecology approach to analysing environmental issues and human/non-human processes. The article considers some of the major aspects of the environmental security literature, before assessing its major weaknesses. It then proceeds to develop a complex

*Corresponding author. Email: e.calvo@uel.ac.uk 
ecology framework inspired by an engagement with complexity approaches and grounded in social ecologism. The final section indicates how such an approach overcomes the weaknesses identified in the environmental security literature.

\section{International relations, security and the environment}

Increasing concerns about the environment, most evident in the issue of climate change, have combined with changing notions of what constitutes security. However, 'environmental security' is a much contested concept. As Levy notes "both "environment" and "security" are flexible enough to mean almost anything one wishes' (Levy 1995, p. 37). There is no consensus on what is meant by 'security' and what is included under the term 'environment'. Global environmental change presents an incredible challenge for current approaches to security in the discipline of international relations, because, as Dyer (2001, p. 68) points out, it presents 'concerns which are qualitatively different from traditional security threats'.

Given this, it is perhaps unsurprising that International Relations has had a problematic engagement with environmental questions. This is perhaps because a subject that is analytically state centred (albeit with a focus on inter-state relations) has difficulty in dealing with problems that transcend state borders. Despite a broadening of the security agenda, a more traditional approach to thinking about the ways in which environmental issues may impact global relations is apparent: environmental degradation as a cause of conflict. This focus on the environment as a source of conflict has not only been a concern to writers within International Relations, it has been an issue discussed by politicians, the popular media, and international organizations. A United Nations Environmental Programme report, for example cited environmental issues being central to the conflict in Darfur (UNEP 2007, p. 8).

In a recent review of the literature on environment and security Detraz (2009) suggests that three main approaches can be identified: environmental conflict, environmental security and ecological security. This typology usefully distinguishes quite different approaches which have previously all been included under the umbrella term of environmental security, and are summarised in the table below. 


\begin{tabular}{|l|l|l|l|l|}
\hline & $\begin{array}{l}\text { Referent/Level } \\
\text { of Analysis }\end{array}$ & Perspective & Source of Insecurity & \multicolumn{1}{|c|}{$\begin{array}{c}\text { Key } \\
\text { Examples }\end{array}$} \\
\hline $\begin{array}{l}\text { Environmental } \\
\text { Conflict }\end{array}$ & State & Realist & $\begin{array}{l}\text { Environmental } \\
\text { change, or resource } \\
\text { depletion }\end{array}$ & Klare \\
\hline $\begin{array}{l}\text { Environmental } \\
\text { Security }\end{array}$ & $\begin{array}{l}\text { Individual, or } \\
\text { sub-state } \\
\text { community }\end{array}$ & Liberal & $\begin{array}{l}\text { Environmental } \\
\text { change, or resource } \\
\text { depletion/degradation }\end{array}$ & $\begin{array}{l}\text { Eckersley, } \\
\text { UN }\end{array}$ \\
\hline $\begin{array}{l}\text { Ecological } \\
\text { Security }\end{array}$ & Biosphere & Ecological & Human activity & Dalby \\
\hline
\end{tabular}

A clear example of the environmental conflict literature is Klare's discussion of Resource Wars. Access to resources is 'becoming an increasingly prominent feature of American security policy' (Klare 2001, p. 6). Wars of the future 'will largely be fought over the control and possession of vital economic goods especially resources needed for the functioning of modern industrial resources' (Klare 2001, p. 213). For many the US and British invasion of Iraq would seem to present a clear example of such a resource war. Paul Wolfowitz's comment that 'economically we just had no choice in Iraq. The country swims in a sea of oil' (quoted in Kaldor et al. 2007, p. 1) would appear to confirm the invasion as a clear instance of 'petroimperialism' (Jhaveri 2004).

While retaining a focus on access to resources, other authors have provided a more nuanced account of the relations between resource availability and conflict, at both a state and sub-state level. Renner (2002, p.6) argues that in 2001, about one quarter of the approximately 50 violent conflicts in the world had 'a strong resources dimension'. Renner draws attention to the point that it is not only resource scarcity that can prompt conflict, resource wealth can also provide a significant contribution to conflict. Conflict diamonds are a notable means by which conflict in Africa has been financed (Lujala et al. 2005); while in Colombia control over cocaine production has been a major source of finance for both sides in the civil war. LeBillon (2005, p. 23) argues that 'natural resources have become the economic mainstay of most wars in the post-Cold War context'.

It is, as Trombetta (2008, p. 592) has observed, the environmental conflict notion that has 'captured' policy-oriented discussions of environmental issues. John Reid, former British Secretary of Defence warned of the increased risk of violent conflict related to environmental change (Morris and Russell 2006), while the potential links between environmental change and conflict were discussed by the United Nations Security Council in April 2007. Barnett (2001, pp. 71-91) provides a detailed discussion of the ways in which the Clinton administration incorporated environmental security issues into the national security policies of the United States.

Detraz utilises the term environmental security to encompass the literature more influenced by the discussions of human security. As Eckersley notes these analyses reflect the new 'expansive security discourses' (Eckersley 2009, p. 90). 
This literature focuses on the individual or immediate community at risk from environmental change or degradation. One clear example of this has been the development of the notion of 'human security'. The term originates in a 1994 United Nations Development Programme Report, New Dimensions in Human Security (UNDP 1994). Since 1994 the term has entered both popular and academic discussions of security, though within academia it has been a source of considerable controversy (see in particular, the debate in Security Dialogue (2004) 35/3). In New Dimensions in Human Security, the environment was included amongst a list of seven issues that required addressing to ensure human security. While the human security literature provides a welcome relief from the state-centred character of much of the analysis, the focus frequently remains on threats from the environment to humans. Such approaches have been positively appraised as a 'human-centred perspective' within policy fora (Annan, 2005). Yet, they can also be criticised on these same grounds in terms of a failure to consider the wider biosphere and the impact of human activities within that broader context. In addition, human security, often with a focus on the global poor, has been insufficiently attentive to cross cutting forms of social inequality, for example, the feminisation of poverty.

Ecological security, by contrast, refers to those analyses which focus 'on the negative impacts human behaviors have on the environment' (Detraz, 2009, p. 351). We consider the work of Dalby to be an example of such an approach. Dalby (2002b) has been critical of elements of theorizing within the environmental security field, and has raised important questions about conceptualizing environmental problems in security terms. Whilst he goes as far as to suggest that we should consider whether to abandon the notion of 'environmental security' altogether (Dalby, 2009, p. 4), he ultimately draws back from this. He argues that human beings have changed the 'circumstances of life' in ways that mean the environment we are attempting to secure is one which is increasingly artificial. Human lifeways have modified our environment to the extent that we have remade the environmental context of our own existence. Dalby (2009, pp. 97-104) uses the geologically inflected term developed by Crutzen, 'the anthropocene', in order to capture this. Dalby's account is influenced by certain kinds of political ecologism and draws on some complexity approaches. This 'ecological security' approach represents a significant improvement on 'environmental security' and certainly, on approaches emphasizing 'environmental conflict'. Whilst sophisticated, this analysis still underplays the political significance of social difference. Complex systems of power in the social world are cross-cutting and intersected. Whilst Dalby considers the problematic effects of carboniferous consumer capitalism, and relations between rich and poor regions and peoples in his analysis, he scarcely considers gender. Our articulation of complex systems deploys the feminist concept of social intersectionality in trying to capture the range of multiple, complex inequalities that shape human relations with 'the environment' and resultant environmental insecurities.

Despite this range of approaches to environmental security, specific interventions can be seen as problematic, and this raises questions about the application of 'security', however broadly defined, in analyzing both environmental problems and associated risks for human populations, and intra-human 
vulnerabilities. International Relations with its tradition of state-based analysis, has difficulties in dealing with the global character of many environmental issues. Both the globalised character of some environmental problems needs to be fully appreciated, whilst also being cognisant of the differential impact of problem effects in the context of profound and persistent inequities.

Global warming is the clearest and most pressing example of a global environmental problem. Other environmental issues may not be so 'global' in impact. Land pollution is often localised; humans pollute land where they bury industrial and consumer waste, or locate industrial processing. However, the international trade in commercial and industrial waste, and the practices of dumping waste in international waters and on other countries, adds a global dimension. The pollution of seas is global, as almost all seawater is connected; as is air pollution, carried over considerable distances by prevailing winds (Yearley 1996, p. 33-34). The loss of species biodiversity has also come to be defined as an environmental problem for the maintenance of healthy ecosystems, and the extent of this collapse has been labelled the 'sixth extinction' (Leakey and Lewin 1996).

This said, most authors argue that the impacts of global climate change will have greater impact on the South. Devereux and Edwards argue that the effects of global warming will be 'globally stratifying'. Those countries where drought is already a problem are likely to become drier. These same countries are more dependent on agriculture where the possibilities for diversification are more limited. It is likely, they argue, that 'the prevalence and depth of hunger will deteriorate in those countries and population groups where food security is already significant' Devereux and Edwards 2004, p. 28). Goldblatt (1996) argues that the exploitation of the South's environment commenced during the colonial period and has continued since the end of the European empires. In this sense the 'North' has exported much of its environmentally damaging industrialisation, making the notion of environmental security on a national basis nonsensical.

In addition, the extent to which gender inequalities differentiates human causes of environmental changes and their effects, is absent from most accounts in the environmental security literature. Salleh argues that the impact of gender inequalities is absent from the notion of ecological footprint that has been used in an essentialist way, as it differentiates humanity only in terms of Northern or Southern location (Salleh, 2009, p.11). This ignores the gendered qualities of paid and unpaid work and of transport and energy use and the feminisation of poverty. Collectively, as Spitzner notes, these inequalities mean that both the causes and consequences of global warming are gendered (2009, p. 218-222). An exception here is the work of Ursula Oswald Spring (2007, 2008a, 2008b) who has suggested a conceptualisation in terms of "human, gender and environmental security" or "HUGE". Oswald Spring combines a "broad" understanding of gender in terms of vulnerability rather than, as she suggests (somewhat simply) the more traditional approach of inequality. A key and strength of this work is the placing of gender on environmental security agendas, and of equal significance, an attempt to mainstream issues of intra-personal violence as systemic and structural in terms of the vulnerability (of elders, woman and children) in situations of environmental and other conflict. However, there are a 
number of drawbacks with the HUGE formulation. First, the conceptualisation of gender conflates the specific vulnerabilities of adult women and elders and children of both sexes. It is insufficiently complex and we would argue, does not see these differences as intersectionalised; that is, radically differentiated through the crosscutting, qualitatively and quantitatively impacting effects of inequities and differences of age and cultural context. In an undifferentiated model of 'patriarchy' it does not account, for example, for regional systemic formations of gender regime (Walby, 2007). Second, the notion of gender security as vulnerability does not draw together the links between the vulnerabilities of communities (of indigenous minorities for example) with those of non-human animals, and the co-dependencies of these communities with/in 'natural' systems. The use of the term 'security' may certainly have helped with policy mainstreaming, but it is framed by a static and homogenous analysis of gender relations and carries a risk of statism associated with mainstreaming generally. These problems of social difference - of region, location, gender, age, cultural specificity, species and so on, require, as we will argue a complex systems approach.

Second, and ironically, territorial states are in many ways foundational for securitisation approaches, but as Dalby (2002c, p. 5) notes, charging states with responsibility for the environment may well be a case of foxes guarding chickens. States have been drivers for modernisation, putting in place infrastructure dependant on carbon fuels and high levels of resource use, in large part, by establishing a capitalist system (Latouche 1993). The fundamental question is whether states, and the international organizations of which they are members, can construct new physical and institutional infrastructures which move us away from an ever expanding use of resources. Much of what we have seen in terms of the internationalization of environmental policy involves an assumption that economic growth can be compatible with ecological sustainability and 'there is a technoinstitutional fix for the present problems' (Hajer 1995, p. 32). The politics of ecologism however, imply radical departures from our currently normative economic, political and social practices in wealthy Western/Northern states, and has been extremely pessimistic concerning the ability of states to deliver change (Sachs et al. 1998). Eckersley (2004, p. 241), however, is confident that a decline in territorially based governance accompanying globalization, coupled with a radical institutional reform, will make possible the consideration of ecological concern. She suggests a move from liberal democracies to 'ecological democracies', where those collectivities subject to ecological risk must be involved in or represented in decision-making which may involve or generate ecological risk. Yet it is most uncertain that globalization has actually reduced the power of states, and international political organizations remain limited in both authority and power. Rather reforms undertaken by states and supranational institutions tend to be a process in which environmental questions are subsumed under a bureaucratic rationality of resource managerialism (Luke 1999). The logic of capitalist development, albeit linked with 'sustainability' is foundational for environmental policy initiatives (Clack and York 2005). State derived security, as Neocleous (2008, pp. 185-186) suggests, is a 'gift' that we might like to return. 
In addition, this statist focus has resulted in a tendency to associate issues of security with military solutions. Deudney has argued that the use of the term 'security' links the environment too closely to questions of national survival. Such an association may lead to inappropriate polices, especially the prioritising of military solutions over diplomatic methods (Deudney 1990, pp. 465-469). There is evidence that the leaky nature of environmental insecurities has also led organizations concerned with transnational security to take seriously non-military threats. NATO had a team of researchers employed from the late 1990s with the task of ascertaining which environmental matters might contribute to international conflict (as discussed by Dalby 2002a, p. 97). A report produced by a group of retired US military personnel concluded that "climate change can act as a threat multiplier for instability in some of the most volatile regions of the world, and it presents significant national security challenges for the United States' (CNA 2009). Some suggest therefore, that we have witnessed a 'greening' of the military' wherein security organizations are increasingly deployed in realizing environmental goals (Matthew 2002, p. 118). Yet there may be unintended consequences of this link. Extending the notion of security to the environmental sphere, according to Brock (1997, p. 21), might 'actually broaden the range of arguments for justifying military action'. Hence a link to security might have unexpected and undesirable consequences: the prioritisation of coercive solutions over diplomatic approaches to environmental issues, and the legitimation of other forms of intervention.

Finally, the environmental security literature tends to reproduce a dualistic understanding of human relations to 'the environment' in which 'we' humans are either threatened by or pose a threat to 'nature' (Barnett 2001, p. 67). Such a dualism becomes apparent in the typology advocated by Detraz, wherein either the environment is a threat to the state (environmental conflict) or the individual (environmental security), or the biosphere itself is under threat (ecological security). As Dobson (2006, p. 180, emphasis in original) has argued this 'idea of a boundary has always existed' and is arguably 'crucial to our self-conception as human beings.' For Latour (2004, p. 53) "the terms "nature" and society" do not designate domains of reality: instead they refer to a quite specific form of public organization'. Latour argues that we need to adapt current institutions to give a voice to a single collective of humans and non-humans. Likewise Walker (2006, p. 189) argues that politics itself is constituted by 'a profound rupture between man and nature'. In other words there is an ontological issue which the environmental security literature highlights most profoundly. Dualism underestimates the complex interlinkages in the biosphere, by focusing on the security of one referent rather than allowing an analysis which permits the examination of the complex and overlapping processes that constitute environmental problems. The term 'environment' itself, is a catch all category which homogenises the diversity of non-human life and encompasses a multiplicity of incredibly varied non-human plant and animal species. Such an understanding of the 'environment' and the distinction of the human species from it is a product of Western histories and sensibilities (Soper 1995). Human modifications of our habitat(s) are shaped by histories of social relations, economic practices and formations of political power. 
We consider that two moves are required in order that International Relations produce an understanding of environmental questions which is not either foundationally dualist and state centric, or which contains some essentialism of 'the human'. First we need an approach which understands the embedded situation of the human species in networks and scapes populated with non-humans. Second, we need an approach that can account for different kinds of power relations. We favour a social ecologism which takes account both of our imperative need to care for the biosphere, together with an understanding of the ways in which multiple and complex inequalities shape the securities of different populations. For this, we consider that an understanding of difference and inequalities as intersectionalised is necessary. We will argue that elements of complexity theory can assist both moves.

\section{Complex systems, social difference and ecopolitical theory}

'Complexity theory' is something of a misnomer for a range of theories and concepts. When complexity scientists use the term 'complexity', they do so to describe the occurrence of complex information in which order is emergent (Hayles 1991, p. 176), whilst not being fixed, static or absolute (Hayles 1990, p. 292). At one of the leading centres of complexity science, the Santa Fe Institute in New Mexico, there have been concerted attempts to theorize what we might call ecological insecurity. This has been envisaged as an area of unacceptable risk to human and natural systems, requiring radical changes in economic and social organization and practice, and a new approach to international political relations (Waldrop 1994, p. 349-352). In turn, the social sciences have increasingly been faced with the problem of dealing with phenomena that cannot be seen as 'purely' social but are hybrid formations (Urry 2003, p. 17). Complexity approaches provide a rich source in attempting to transcend unhelpful, but powerful, dichotomies between the 'social' and 'natural' worlds and the disciplines of their study. In order to make the link between complexity approaches and environmental issues, we draw upon different strands of political ecologism in order to tease out the ways in which they understand human-environment relations as a system of social relations, and in some accounts, one which is also constituted through intra-human relations of systemic inequality. First however, let us consider the case for drawing complexity concepts into the analysis.

In complexity science, natural systems are understood to exist in a web of connections with other systems and are internally complex. The term 'emergent properties' describes specific qualities that emerge at a certain level of systemic complexity that are not apparent at lower levels. Thus in ecology for example, systems are understood as communities of organisms which link together in a network (Capra 1996, p. 34-5). Complexity scientists often speak of systems as 'nested', with lager scale systems enclosing myriad smaller scale systemic processes (Holling et al. 2002c, pp. 68-9). One of the most common and simple elements of the complexity notion of system, is the distinction between a system and its environment. A system has boundaries, is delimited and distinguishes itself from its 'environment', that is, everything external. Although distinct, systems interact with 
one another in a way which has been referred to as 'coupling' (Maturana and Varela 1980, p. 109). Coupled systems may themselves be self reproducing, so they may come to depend on each other for the preservation of their identities.

Systems have 'autopoiesis' and are self-making, self-defining or regulating. Neuroscientists Maturana and Varela (1980, p. xvii) considered that in adapting and recreating the conditions of life, natural systems should be seen as engaging in a process of cognition. A system then, has internal processes which internally connect its elements and actively reproduce the system as a whole. A controversial and wellknown model is Lovelockian earth systems science. Lovelock (2000) developed the hypothesis that the earth was a 'superorganism' able to regulate its own temperature. A vast network of feedback loops bring about such regulation, and link together living and non-living systems. There are different levels of organised complexity here, and social and natural systems are interlinked.

Changes are processed by systems through feedback loops which synthesise new information and result in the dynamic qualities of systems. Feedback can result in stability, or if there is positive feedback and change is reinforced rather than dampened down, dramatic shifts can take place and a system can be said to have become 'path dependent'. Natural systems are characterised in this view by constant, unpredictable and sometimes dramatic change. Systems change though interaction and the notion of co-evolution describes how systems complexly adapt to their environment. Rather than simply impacting on one another (as implied by a hierarchical model of system) systems have complex reactions to relations with other systems (due to the presence of their own internal systemic features). All individual interacting systems, often of different levels of complexity and scale are changed in their interaction.

These concepts may be usefully developed in the study of social and political life. They allow for differentiated systems, with various layers and levels of emergent properties and powers, and do not assume that relationships between levels are fixed or hierarchical in character. In addition, there is the presumption that systems interrelate, overlap each other, may exist within each other and are coconstitutive. There is no presumption of stasis, but rather, the notion that systems are constantly making and remaking themselves. This understanding of ecosystems has underpinned some of the stronger work on environmental security (see Dalby, 2009, pp. 78-104) but the foundational concepts for such theorizations have not been drawn through in such work in terms of theorizing human systems interactions with non-human systems. Into this general theorization (or meta-theorization) of systems as complex, we need to integrate the analysis of relational systems of intra-human power and inequality, and an understanding of the systemic relations of the diversity of human populations with/in non-human systems. In doing so, we now turn to elements of political ecologism.

Deep ecologism already adopts a systemic approach to understanding the organization and patterning of both social and natural life. All processes are connected and human intervention in natural ecosystems cannot be without impact. Naess (1989) suggests that living beings of all kinds are 'knots' in a biospherical field of relations. Such webs of relationships are incredibly complex and need to be 
understood as vast systems (Eckersley 1992, p. 49) that interlock us with a variety of species and scapes. This reflects the understanding of some complexity theorists, that social, political and economic practices are ecologically embedded (Capra, 2003). In addition, a strength of deep ecologism is that it understands human society as structured in particular relations with the 'natural world'. A system of relationships termed 'anthropocentrism'. Western society is human-centred in its organization and has a dominant worldview in which non-human natures are conceptualised in terms of means to human ends. Eckersley deploys anthropocentrism in a way that marginalises human diversity and relations of intrahuman power, for example by using the term 'human-racism' to critique those who do not subscribe to her understanding of the intrinsic value of non-human life forms (Eckersley 1999:38). We would retain this notion of social relations with 'the environment' as systemic and exploitative, and in turn constituting a threat to human security. However, we also want to draw on complexity concepts and different kinds of social ecologism, in order to unpack the 'human'.

In feminism, the theorization of multiple differences and inequalities has been difficult and contested. Some of those attempting to understand the cross cutting of multiple social inequalities (of ethnicities, class and so on) with gender, have used the term 'intersectionality' to emphasize the ways social differences and dominations are mutually constitutive. The effects of, for example, 'race' for gender are not simply an overlapping of inequalities. Gender relations, through intersection, change the properties of 'race' (McCall, 2005; Phoenix and Pattynama, 2006). Surprisingly, even feminist and Marxist inflected accounts which have drawn on complexity theory (such as Byrne, 1998; Nowotny, 2005) have not used it to account for the intersection of complex relations of social domination (albeit with notable exceptions, Walby 2007). The uses of complexity in social theory have also often also been unashamedly anthropocentric in conceptualizing the social as exclusively human. Yet complexity is a framework in which the operation of interrelated social and 'natural' systems might be captured.

Human relations with the environment are socially intersectionalised, that is, existent in a context overlapping relations with other systems of social relations, such as those based on class, gender and ethnic hierarchy. What are often called 'social' ecologisms have accounted for the interplay between human domination of nature, and our various kinds of systemic domination of each other (Bookchin 1990, p. 44). Systemic analyses of capitalism have been deployed in order to understand environment-society relations. Dickens (1996) suggests that the nexus of environmental exploitation is the social organization of labour power in capitalist societies around the production of goods for the market. A complexity reading of Marx has been developed by Harvey (1996, p. 187) in suggesting that local actions (for example, the exploitation of workers) reproduce the capitalist system and its emergent properties (for example, class relations, resource depletion) and give rise to various system contradictions (from social movements to environmental collapse).

Environmental difficulties are also seen to be embedded in the social relations of (post)colonialism, causing specific problems in particular, across the regional formations of the global South (Peet and Watts 1996, p. 14). This is 
compatible with complexity analytics in that specific social/natural formations are understood as produced by a range of interrelating social and natural structures and processes, and because these localised systems of environmental exploitation and human injustice have impacts beyond the region in which they are located, and have global effects. Whilst Dalby (2009), does account for the differences between Northern and Southern regions and states, and the structuring of global capitalism on human-environment relations, he has very little indeed, to say of gender inequalities and the complicating qualities of the ways in which these intersect with those of capital and place.

Whereas postcolonial and socialist ecologism is not fully intersectionalised in its analysis, ecofeminism provides a version of social ecology in which the domination of nature is interrelated particularly with gender, but also with a range of other forms of systemic inequalities. In some accounts, a full range of intersected differences is not accounted for. Oswald Spring (2008a), discussed earlier, does not account for the socialnatural impacts of global capitalism, for example. In other accounts, such as that of Mies (1998), this is key, and the gendered division of labour is at the core of the linked exploitations of women by men, southern countries by wealthy northern global powers and the natural environment by human society. From an ecofeminist perspective, Salleh has emphasised that a rounded, 'triangulated' political ecologism would integrate the analysis of gender relations, north-south relations and those of capital, into an understanding of human relations with 'nature' (2009, p. 3-5). Cudworth (2005) has argued that ecofeminist analysis would be enhanced by understanding systems of social domination (such as patriarchy, capitalism and the domination of the natural world) as analytically distinct but overlapping, and deployed complexity concepts in articulating how they are interrelated, co-constituted and multi-levelled.

All these political ecologisms see human communities in a complex network of relations with non-human nature - relations characterised by reciprocity and interdependency, and also importantly, by exploitation and domination. We take from deep ecologism that there is a social system of human domination, but consider that this takes historically and geographically specific formations. Such domination is linked to multiplicitious intra-human formations of domination. It is here that complexity theory can help us to consider intermeshing multiple systems. We conceive these systems as both analytically distinct, whilst being also, mutually constitutive. The domination of non-human nature is a system of exploitative relations, that overlaps and interlinks with other systems of power and domination based on gender, capital, ethnic hierarchy and so on.

In addition to a conception of different systems of social power that are complex and intersected, it is important to capture the scales and levels of different kinds of systems. Useful here is the notion of 'panarchy' which draws in ecosystems, political, economic and social systems, alongside a notion of local, specific human cultural systems (Holling et al. 2002c, p. 72). Panarchies are living systems, conceived of as internally dynamic and historically non-static structures which develop mutually reinforcing relationships which are co-constitutive and adaptive. It is not only panarchies involving human systems which demonstrate 
decision making properties, rather a huge variety of non-human animals make collective decisions and engage in individual decision making behaviour with a cumulative systemic effect (Holling et al. 2002c, pp. 72-87). Living systems of humans, non human animals and plants develop self-organised interactions with physical processes. These self-organised interactions do not result in stability. Rather, systems may be vulnerable - ecosystems may collapse or be undermined by human endeavours, political systems may be vulnerable due to the collapse of natural systems on which populations depend for resources, or social shifts (such as economic exploitation, increased literacy rates and so on). Importantly also, systems in interaction are themselves complex systems with their own emergent properties (Holling et al. 2002b, p. 411).

This kind of theorizing allows for some qualitative and quantitative differences between 'natural' and 'social' systems, in particular, because the selforganizing properties of intra human systems outstrip those of natural systems (Westley et al. 2002, pp. 104-5). Whilst social and natural systems may be shaped and structured by similar processes, social systems have properties of consciousness and reflexivity. They also reproduce and develop formations of social power, which, like capitalism, patriarchy and so on, are usefully understood as complex adaptive systems. There are systems of social power relations, ecosystems and various levels of systems and structure in the social world that give rise to a multiplicity of forms of local, regional, global configurations of socialnature (Haraway2003). In what ways might such an analytics and politics be incorporated into the study of environmental issues in international politics?

\section{Beyond environmental security: complex ecologism}

A complexity-inspired approach to environmental issues in international relations would constitute a distinct form of analysis compared to 'environmental conflict' and 'environmental security' approaches. Such an approach gives priority to developing an understanding of social, political and economic relations as impacting beyond the human. While human and non-human systems have distinct features, ultimately they are co-constitutive, overlapping and intersected. Rather than seeing a separation between the human and the non-human, complex ecologism sees the human world as embedded within the natural world, with the variety of human social systems intersecting with those of other natural systems.

There are a few attempts to deploy complexity in 'ecological security approaches'. Harrison, for example, identifies 'four principle concepts of complexity adapted to ecological systems': adaptive agency, self-organizing emergence, authority and openness' (2006, p. 55). There are two major difficulties with Harrison's application of complexity concepts: dualism and the eliding of power relations. Harrison discuses the concept of agency entirely in relation to the subjectivity and adaptation strategies of human beings in the context of environmental change. The agencies of other species which are supposedly coevolving with those human agents, is absent. Second, in his discussions of selforganisation and emergence, he stresses the bottom-up interconnections and 
processes for example, in environmental policy making. In Harrison's interconnected, non-linear systems, natural and social systems are analytically separate and the politics of ecologism is lost - there is no understanding of power in the social world here, or its impact on non-human systems.

Whilst 'ecological security' firmly places the analysis of political, social and economic relations within the global environmental system, and pays attention to regional differences, it does not account for the full range of complex social inequalities that shape human relations with, and within, environments. The contribution of a complex ecology approach is the potential to analyse intersectionality and multiple power relations. As discussed above, a variety of different sets of power relations have been analysed by political ecologists. These represent the operation of different sets of systems, such as patriarchal, capitalist, ethnocentrist etc., which can have an impact on each other, and have implications for the environment. We would argue that, while these can be considered as distinct systems, the development path of each has implications for other systems. This allows for the development of multiple levels of analysis, drawing the focus away from the state, to supra-state levels (including the biosphere) and sub-state levels.

Complex ecologism provides a means of overcoming the weaknesses in the range of environmental securitization approaches as discussed in the first section of this paper. By moving away from a state focussed framework, and considering a panarchy of inter-linked systems, environmental problems can be considered at global, regional and local levels. The biosphere itself is a system co-constitutive with other human and non-human systems. Envisioning human systems embedded within a wider range of systems overcomes the duality inherent in the majority of approaches to understanding environmental issues within international relations. The environment is not "out there", but instead constitutive of, and reactive to, human systems. Human systems are embedded within a number of non-human systems, with the consequence that developments in one system may have implications elsewhere in the panarchy. Thus, as a simple example, increased carbon dioxide levels as a result of increased industrialisation can be linked to species migration in local ecological systems. Likewise global temperature rises can increase energy use (often in gender differentiated ways), impacting across economic (oil prices), political (inter-state relations), and ethnic systems (relations with the Middle East).

The interlinking of complex systems also allows the analysis to shift from a focus on security to one of insecurity. Complex ecologism understands interactions and changes in complex human/natural systems as resulting in multiple risks, hazards and uncertainties, which international politics must navigate. A significant feature of current global environmental issues is that many of those most in a situation of risk are not the authors of the causes of that risk. Environmental risk situations faced by individuals, communities, and societies are frequently the consequences of complex power inter-relationships. More developed societies have been effective at exporting their pollution, gaining the benefits of industrial production without the inherent environmental costs. The populations of small lowlying islands in the Pacific, whose societies are put at risk from rising sea-levels, are not the beneficiaries of large-scale industrialisation. 
Finally, by focussing on the intersection of power relations operating in and between different systems, and the creation of risk that is associated with relations between systems, the possibilities for a mitigation of risk throughout the panarchy become the key issue. The move from 'security' to 'risk alleviation' implies that the focus of attention is on the re-structuring of risk-creating activities, rather than attempts to secure protection for specific groups. From such a viewpoint, the possibility of this ultimately being perceived as a situation requiring a military solution becomes less viable. By breaking the link between this as a state-focussed issue, and instead a concentration on an analysis focussed on intersecting systems, removes the focus on particular social groups, and re-orientates the analysis towards both a concern for the wider biosphere and social justice. As many others have pointed out, work on environmental change in international relations theory has tended to modify existing approaches by including the environment in pre-existing frameworks, such as securitization. Perspectives such as 'ecological security' which attempt a radical questioning and transformation of that framework are still shaped by it. We need to move beyond securitization.

\section{Conclusion}

A complex ecologism provides a politics and an analytics that takes account both of our imperative need to care for the biosphere, together with an understanding of the ways in which multiple and complex inequalities shape the securities of different populations. The environmental security approach is significant for the way in which it has prioritised the issue of the global environment, yet the way it has prioritised the state, and seen the environment as something 'out there' from which security can be provided has led to limitations as way of seeing human/non-human relations and theorizing international environmental politics. Complex ecologism stresses the embeddings of human systems within a panarchy, and implies that the alleviation of environmental crises involves, not the provision of security, but rather a reorientating of human activity, which will reduce the risks for all systems within the biosphere.

We have argued that complexity theory enables a number of important theoretical moves. It enables the capture of the ontological depth of relational systems of social inequality and their interaction or intersection. It is a transdisciplinary approach that most usually assumes the co-constitution and coevolution of social with natural systems. In understanding systems, both social and natural, as dynamic, non-linear and unpredictable however, environmental 'issues' and 'problems' have multiple causes and consequences from which no species can be 'secured'. We live in a matrix of multiple risk. The politics of social ecologism (broadly defined and including insights from Marxist, feminist and postcolonial approaches) suggests that the way to face hazard may be to take concrete steps to regulate the uneven flow of resources from poor to rich, institutionalise and normativise the practices and ideals of social justice. In addition, those developments should take account of the complex relationships of interdependency between human communities and the 'natural environment'. Yet whilst this might 
suggest a policy agenda for the attempted control of risk, our complex ecologism suggests something more. Carboniferous consumer capitalism, the injustices of gender relations and colonialism need to become less 'secure', and this would entail a reconceptualisation of dominant economic relations and social practices and a reinvention of our political world.

\section{References}

Annan, K. 2005. In Larger Freedom: development, security and human rights: The Millenium Report. New York: ONU.

Barnett, J., 2001. The meaning of environmental security: ecological politics and politics and policy in the new security era. London: Zed.

Bookchin, M., 1990. The philosophy of social ecology. Montréal: Black Rose Books.

Brock, L., 1997. The environment and security: conceptual and theoretical issues. In: N.P. Gleditsch, ed. Conflict and the environment. Dordrecht: Kluwer Academic Press, 17-34.

Byrne, D. 1998 Complexity Theory and the Social Sciences. London: Routledge.

Capra, F., 1996. The web of life: a new synthesis of mind and matter. New York: Harper Collins.

Capra, F., 2003. The Hidden Connections: A Science for Sustainable Living. London: Flamingo.

Castree, N., 2001. Marxism, capitalism and the production of nature. In: N. Castree and B. Braun, eds. Social Nature. Oxford: Blackwell, 189-207.

CNA, (2009) National Security and the Threat of Climate Change. Available at http://securityandclimate.cna.org/report/.

Clack, B. and York, R., 2005. Carbon Metabolism: Global Capitalism, Climate Change, and the Biospheric Rift. Theory and Society, 34(4), 391-428.

Cudworth, E., 2005. Developing eco-feminist theory: the complexity of difference. Basingstoke: Palgrave.

Dalby, S., 2002a. Security and ecology in the age of globalization. Environmental Change and Security Report, 8, 95-108.

Dalby, S., 2002b. Environmental security. University of Minnesota Press.

Dalby, S., 2002c. Environmental security: ecology or international relations. Paper presented at the annual convention of the International Studies Association, March 2002, New Orleans, USA.

Dalby, S. (2009) Security and environmental change. Cambridge: Polity.

Deudney, D., 1990. The case against linking environmental degradation and national security. Millenium, 19 (3), 461-476. 
Detraz, N., 2009. Environmental security and gender: Necessary shifts in an evolving debate. Security Studies, 18(2), 345-369.

Devereux, S. and Edwards, J., 2004. Climate change and food security. IDS Bulletin, 35, 22-30.

Dickens, P., 1996. Reconstructing nature: alienation, emancipation and the division of labour. London: Routledge.

Dobson, A., 2006. Do we need (to protect) nature? In: J. Huysmans et al, eds. The Politics of Protection: Sites of Insecurity and Political Agency. London: Routledge, 175-188.

Dyer, H., 2001. Theoretical aspects of environmental security. In: E. PetzoldBradley, A. Carius and A. Vincze eds. Responding to environmental conflicts: implications for theory and practice. Dordrecht: Kulwer Academic, 67-82.

Eckersley, R., 1992. Environmentalism and political theory: toward an ecocentric approach. London: University College London Press.

Eckersley, R., 1999. Discourse ethics and the problem of representing nature. Environmental Politics. 8 (2), 24-49.

Eckersley, R., 2004. The green state: re-thinking democracy and sovereignty. Cambridge, MA: MIT Press.

Eckersley, R., 2009. Environmental security, climate change, and globalizing terrorism. In: D. Grenfell and P. James eds. Rethinking insecurity, war and Violence: Beyond Savage Globalization? London: Routledge, 85-97.

Goldblatt, D., 1996. Social Theory and the Environment. Cambridge: Polity.

Hajer, M., 1995. The politics of environmental discourse: ecological modernization and the policy process. Oxford: Clarendon.

Harrison, N. E., 2006. From economics to ecology: toward a new theory for international environmental politics. In: E. Laferriere and P. J. Stoett eds. International ecopolitical theory: critical approaches. Vancouver: University of British Columbia Press, 52-69.

Harvey, D., 1996. Justice, nature, and the geography of difference. Oxford: Blackwell.

Haraway, Donna, J. 2003. The companion species manifesto: Dogs, people and significant otherness Chicago: Prickly Paradigm Press.

Hayles, N.K., 1990. Chaos bound: Orderly disorder in contemporary literature and science. Ithaca: Cornell University Press.

Hayles, N.K., ed., 1991. Chaos and order: Complex dynamics in literature and science. Chicago: University of Chicago Press.

Holling, C.S. et al., 2002a. In quest of a theory of adaptive change. In: L.H. Gunderson and C.S. Holling, eds. Panarchy: understanding transformations in human and natural systems. Washington: Island Press, 3-22. 
Holling, C.S. et al., 2002b. Discoveries for sustainable futures. In: L.H. Gunderson and C.S. Holling, eds. Panarchy: understanding transformations in human and natural systems. Washington: Island Press, 395-417.

Holling, C.S. et al., 2002c. Sustainability and panarchies. In: L.H. Gunderson and C.S. Holling, eds. Panarchy: understanding transformations in human and natural systems. Washington: Island Press, 63-102.

Jhaveri, N.J. 2004. Petroimperialism: US oil interests and the Iraq War. Antipode, 36, 2-11.

Kaldor, M. et al., eds., 2007. Oil wars. London: Pluto.

Klare, M.T., 2001. Resource wars: the new landscape of global conflict. New York: Metropolitan Books.

Latouche, S., 1993. In the wake of the affluent society: an exploration of postdevelopment. London: Zed Books.

Latour, B., 2004. The politics of nature. Cambridge, MA: Harvard University Press.

Leakey, R. and Lewin, R., 1996. The sixth extinction: Biodiversity and its survival. London: Weidenfeld and Nicolson.

Le Billon, P., 2005. The geopolitical economy of "resource wars". In: P. LeBillon, ed. The geopolitics of resource wars. London: Frank Cass, 1-28.

Levy, M., 1995. Is the environment a national security issue? International Security, 20 (2), 35-62.

Lovelock, J., 2000. Ages of Gaia: a biography of our living earth, 2nd ed. Oxford University Press.

Lujala, P. et al., 2005. A diamond curse? civil war and a lootable resource. Journal of Conflict Research, 49 (4), 538-62.

Luke, T.W., 1999. Capitalism, democracy and ecology: departing from Marx. Champaign: University of Illinois Press.

Matthew, R.A., 2002. In defense of environment and security research. Environmental Change and Security Report, 8, 109-124.

Maturana, H. and Varela, F.J., 1980. Autopoiesis and cognition: the realization of the living. Kulwer Academic.

McCall, L., 2005. The complexity of intersectionality. Signs, 30(3), 171-180.

Mies, M., 1998. Patriarchy and accumulation on a world scale (New Edition). London/Melbourne: Zed Books/Spinifex Press.

Naess, A., 1989. Ecology, community and lifestyle: outline of an ecosophy. Cambridge University Press.

Neocleous, M., 2008. Critique of Security. Edinburgh University Press.

Nowotny, H., 2005. The increase of complexity and its reduction. Theory, Culture and Society 22(5), 15-31. 
Oswald Spring, U. 2007. Human, Gender and Environmental Security: A HUGE Challenge. In: U. Oswald Spring, ed. International Security, Peace, Development, Environment. Encyclopaedia on Life Support Systems/UNESCO, Oxford: Oxford University Press.

Oswald Spring, U. 2008a. Gender and Disasters. Human, Gender and Environmental Security: A HUGE Challenge. Bonn: UNU-EHS, Intersection.

Oswald Spring, U. 2008b. A HUGE Gender Security Approach: Towards Human, Gender and Environmental Security. In: Brach, H. G., Grin, J., Mesjasz, C., Krummenacher, H., Chadha, B. Navita, C., Oswald Spring, U. and Kameri-Mbote, P. eds. Facing Global Environmental Change: Environmental, Human, Energy, Food, Health and Water Security Concepts. Hexagon Series on Human and Environmental Security and Peace. Berlin: Springer-Verlag, 1157-1182.

Peet, R. and Watts M., eds., 1996. Liberation ecologies: environment, development, social movements. London: Routledge.

Phoenix, A. and Pattynama, P., 2006. Editorial: 'Intersectionality'. European Journal of Women's Studies, 13(3), 187-192.

Renner, M., 2002. The anatomy of resource wars. Washington DC: World Watch Institute.

Russell, B and Morris, N., 2006. Armed forces are put on standby to tackle threat of wars over water. Independent, 28 February, p. 1.

Sachs, W., 1999. Social justice and environmental sustainability in the postdevelopment era. In: M. Suliman, ed. Ecological, politics and violent conflict. London: Zed Books, 59-75.

Sachs, W. et al., 1998. Greening the north: a post-industrial blueprint for ecology and equity. London: Zed Books.

Salleh, A., 2009. Ecological debt: embodied debt. In: A. Salleh, ed. Eco-sufficiency and global justice: women write political ecology. London: Pluto Press.

Soper, K., 1995. What is nature? Oxford: Blackwell.

Spitzner, M., 2009. How global warming is gendered. In: A. Salleh, ed. Ecosufficiency and global justice: women write political ecology. London: Pluto Press: 218-224.

Trombetta, M.J., 2008. Environmental security and climate change: analysing the discourse. Cambridge Review of International Affairs 21(4), 585-602.

UNDP, 1994. Human Development Report 1994: New Dimensions of Human Security. New York: United Nations Development Programme.

UNEP, 2007. Sudan: post-conflict environmental assessment. Nairobi, Kenya: United Nations Environmental Programme.

Urry, J., 2003. Global Complexity. Cambridge: Polity.

Walby, S., 2007. Complexity theory, systems theory and multiple intersecting social inequalities. Philosophy of the Social Sciences, 2007, 37 (4), 449-470. 
Waldrop, M.M., 1994. Complexity: The emerging science at the edge of order and chaos. London: Penguin Books.

Walker, R., 2006. On the Protection of Nature and the Nature of Protection. In: J. Huysmans et al, eds. The Politics of Protection: Sites of Insecurity and Political Agency. London: Routledge, 189-202.

Westley, F. et al. 2002. Why systems of people and nature are not just social and ecological systems. In: L. Gunderson and C.S. Holling, eds. Panarchy: understanding transformations in human and natural systems. Washington: Island Press, 103-119.

Yearley, S., 1996. Sociology, environmentalism, globalization. London: Sage. 